\title{
Changes in the protein composition of rat spermatozoa during maturation in the epididymis
}

\author{
R. Jones, K. I. von Glos and C. R. Brown \\ A.R.C. Institute of Animal Physiology, Animal Research Station, 307 Huntingdon Road, \\ Cambridge CB3 OJQ, U.K.
}

\begin{abstract}
Summary. Spermatozoa from the testis and cauda epididymidis were solubilized by detergent treatment and electrophoresis on SDS polyacrylamide gels revealed that the relative amounts of 13 detergent-extractable proteins decreased during passage of spermatozoa through the epididymis, 6 increased, whilst the remainder showed little or no change. Lactoperoxidase-catalysed iodination of plasma membrane proteins showed that the components carrying most of the label in testicular spermatozoa had $M_{r}$ values of $110000,94000,84000,55000$ and 42000 whereas on cauda epididymal spermatozoa the $M_{r}$ values were $47000,24000,17000,14500$ and 13500 . Substantial differences were also noted in the protein composition of rete testis fluid and cauda epididymal plasma. The results support the concept that there is a considerable reorganization of the molecular architecture of the plasma membrane of spermatozoa during maturation in the epididymis.
\end{abstract}

\section{Introduction}

The acquisition of motility and fertilizing capacity by spermatozoa during their maturation in the epididymis is accompanied by structural and biochemical changes to the nucleus, mitochondria, acrosome, and plasma membrane (reviewed by Bedford, 1975). However, relatively little is known about how these changes are mediated, in what sequence they take place, or their relative importance for the ability of a spermatozoon to fertilize an egg. Whole cell labelling techniques (Olsen \& Hamilton, 1978; Nicolson, Brodginski, Beattie \& Yanagimachi, 1979; Oliphant \& Singhas, 1979; Vierula \& Rajaniemi, 1980; Voglmayr, Fairbanks, Jackowitz \& Colella, 1980; Young \& Goodman, 1980; Jones, Pholpramool, Setchell \& Brown, 1981; Olson \& Danzo, 1981), freeze-fracture analysis (Koehler, 1970; Flechon, 1974; Suzuki \& Nagano, 1980), and the binding of lectins and antibodies to membrane antigens (Barker \& Amann, 1971; Lea, Petrusz \& French, 1978; Moore, 1980; Koehler, 1981; Jones \& Brown, 1982) have indicated that there is a significant re-organization of the structure of the sperm plasma membrane during maturation. Although changes to the plasma membrane are probably only one facet of the overall maturation process, it is to be expected that they will have significant consequences for intracellular events, e.g. by regulating membrane permeability.

Several workers have reported an alteration in the protein composition of spermatozoa during epididymal maturation (Lavon, Volcani \& Danon, 1971; Brooks \& Higgins, 1980; Olson \& Danzo, 1981). However, accurate identification and quantitation of these changes and information on the organization of proteins in membranous elements is lacking. The aims of the present investigation therefore, were (a) to document any differences between testicular and epididymal (cauda) rat spermatozoa with respect to the nature of proteins solubilized with detergents, and (b) to compare the disposition of proteins in the plasma membrane by using lactoperoxidase-catalysed iodination techniques. 


\section{Materials and Methods}

Materials. Adult male Wistar rats ( $300-350 \mathrm{~g}$ body weight) were used. All chemicals and enzymes were of the highest purity available commercially and were purchased from BDH (Chadwell Heath, Dagenham, Essex, U.K.) or Sigma (London) Chemical Co. (Poole, Dorset, U.K.). Glass fibre filters (GF/C) and nitrocellulose were supplied by Whatman Biochemicals (Maidstone, Kent, U.K.). Pharmacia Ltd (Hounslow, Middlesex, U.K.) supplied protein standards of known size: these were $\alpha$-lactalbumin $\left(M_{r}=14400\right)$, soya bean trypsin inhibitor $\left(M_{r}=20100\right)$, carbonic anhydrase $\left(M_{r}=30000\right)$, ovalbumin $\left(M_{r}=43000\right)$, bovine serum albumin $\left(M_{r}=65000\right)$ and phosphorylase $b\left(M_{r}=94000\right) .{ }^{125} \mathrm{I}(\mathrm{sp}$. act. $15.9 \mathrm{mCi} / \mu \mathrm{g})$ was purchased from Amersham International (Bucks, U.K.).

Collection of testicular and epididymal spermatozoa. Testicular spermatozoa were collected by puncturing the extra-testicular rete testis of rats that had had the efferent ductules ligated for 16-18 h previously. Approximately $100-150 \mu \mathrm{l}$ testicular fluid per rat were collected; the sperm density was $0.5-1.0 \times 10^{8} / \mathrm{ml}$. Spermatozoa were flushed from the cauda epididymidis by retrograde injection of buffered isotonic sucrose $(0.264 \mathrm{M}$-sucrose- $5 \mathrm{mM}$-Hepes $\mathrm{pH} 7.4)$ via the vas deferens. A small bubble of air preceded the buffer to prevent undue dilution of the luminal contents. All manipulations were performed with the tissue under a $\times 8$ stereomicroscope. Spermatozoa were pooled from 6-10 animals for each experiment and motility was checked by phase-contrast microscopy.

The luminal contents from the cauda epididymidis were diluted in isotonic sucrose (approximately $40 \mu \mathrm{l}$ in $1 \mathrm{ml}$ ) and $1-2 \mathrm{ml}$ sperm suspension was layered over $3 \mathrm{ml} 0.3 \mathrm{M}$-sucrose-5 mM-Hepes $\mathrm{pH} 7 \cdot 4$. After centrifugation at $600 \mathrm{~g}$ for $10 \mathrm{~min}$ the sperm pellet was resuspended to approximately $10^{8}$ cells $/ \mathrm{ml}$ in sucrose buffer. Testicular spermatozoa were washed directly as described above without dilution and resuspended in sucrose buffer to approximately $10^{8} \mathrm{cells} / \mathrm{ml}$. Sperm concentration was determined by haemocytometer counts.

Sonication of spermatozoa. Washed spermatozoa were sonicated for $30 \mathrm{sec}$ at $4^{\circ} \mathrm{C}$ (Kerry's Ultrasonics, Model KG 100). This procedure decapitated spermatozoa and extensively disrupted plasma membranes.

Preparation of a membrane fraction from spermatozoa. Washed spermatozoa suspended in sucrose were sonicated as described above and centrifuged at $10000 \mathrm{~g}$ for $30 \mathrm{~min}$. The supernatant was removed and centrifuged another 2 times; once at $20000 \mathrm{~g}$ for $30 \mathrm{~min}$ and then at $100000 \mathrm{~g}$ for 45 min. The final pellet obtained was regarded as the membrane preparation. Electron microscopy showed that it consisted solely of small membrane-bound vesicles (results not shown).

Iodination of plasma membrane proteins on spermatozoa. Spermatozoa were labelled by the procedure of Hubbard \& Cohn (1976). To $1.0 \mathrm{ml}$ of sperm suspension was added $3 \mu \mathrm{l}$ glucose oxidase (14 m Sigma Units/ $/ \mathrm{l}: 0.12 \mu \mathrm{g}$ protein; i.e. 1 unit will form $1 \mathrm{mg}$ purpurogalin from pyrogallol in $20 \mathrm{sec}$ at $\mathrm{pH} 6.0$ and $20^{\circ} \mathrm{C}$ ), $15 \mu$ lactoperoxidase solution ( $365 \mathrm{~m}$ Sigma Units/ $\mu \mathrm{l}: 75$ $\mu \mathrm{g}$ protein; i.e. 1 unit will oxidase $1 \mu \mathrm{mol} \beta$-D-glucose to D-gluconic acid and $\mathrm{H}_{2} \mathrm{O}_{2}$ per min at pH 5.1 and $\left.35^{\circ} \mathrm{C}\right), 5 \mu \mathrm{l}$ glucose solution $(0.56 \mathrm{M})$ and $50 \mu \mathrm{Ci}$ carrier-free ${ }^{125} \mathrm{I}$. The above solutions were added as hanging drops on the walls of the test-tube so that they could be mixed simultaneously. Controls contained all solutions except lactoperoxidase. At 1, 2, 5, 10 and $20 \min 2 \times 20 \mu$ portions were withdrawn, mixed with $100 \mu \mathrm{l} 1$-M-potassium iodide in $50 \mathrm{~mm}$-sodium metabisulphite solution followed by excess cold $\left(4^{\circ} \mathrm{C}\right) 10 \%$ trichloroacetic acid (TCA). Precipitated proteins were collected on glass-fibre filters $(\mathrm{GF} / \mathrm{C}$ ), dried, and counted in a gamma counter (Wallac Decem-GTL 3001000 Series). In some instances precipitated proteins were delipidated by washing filters with $50 \mathrm{ml}$ chloroform:methanol $(2: 1 \mathrm{v} / \mathrm{v})$. The remaining spermatozoa were diluted with 5 volumes of sucrose buffer and washed through $6 \mathrm{ml} \mathrm{0.3} \mathrm{M-sucrose.} \mathrm{Supernatants} \mathrm{were} \mathrm{removed} \mathrm{and} \mathrm{labelled}$ proteins were extracted from spermatozoa as described below.

Suspensions of labelled sonicated spermatozoa were diluted with 10 volumes of sucrose buffer and centrifuged at $100000 \mathrm{~g}$ for $60 \mathrm{~min}$ at $4^{\circ} \mathrm{C}$. The clear supernatant was removed, the walls of the 
PLATE 1
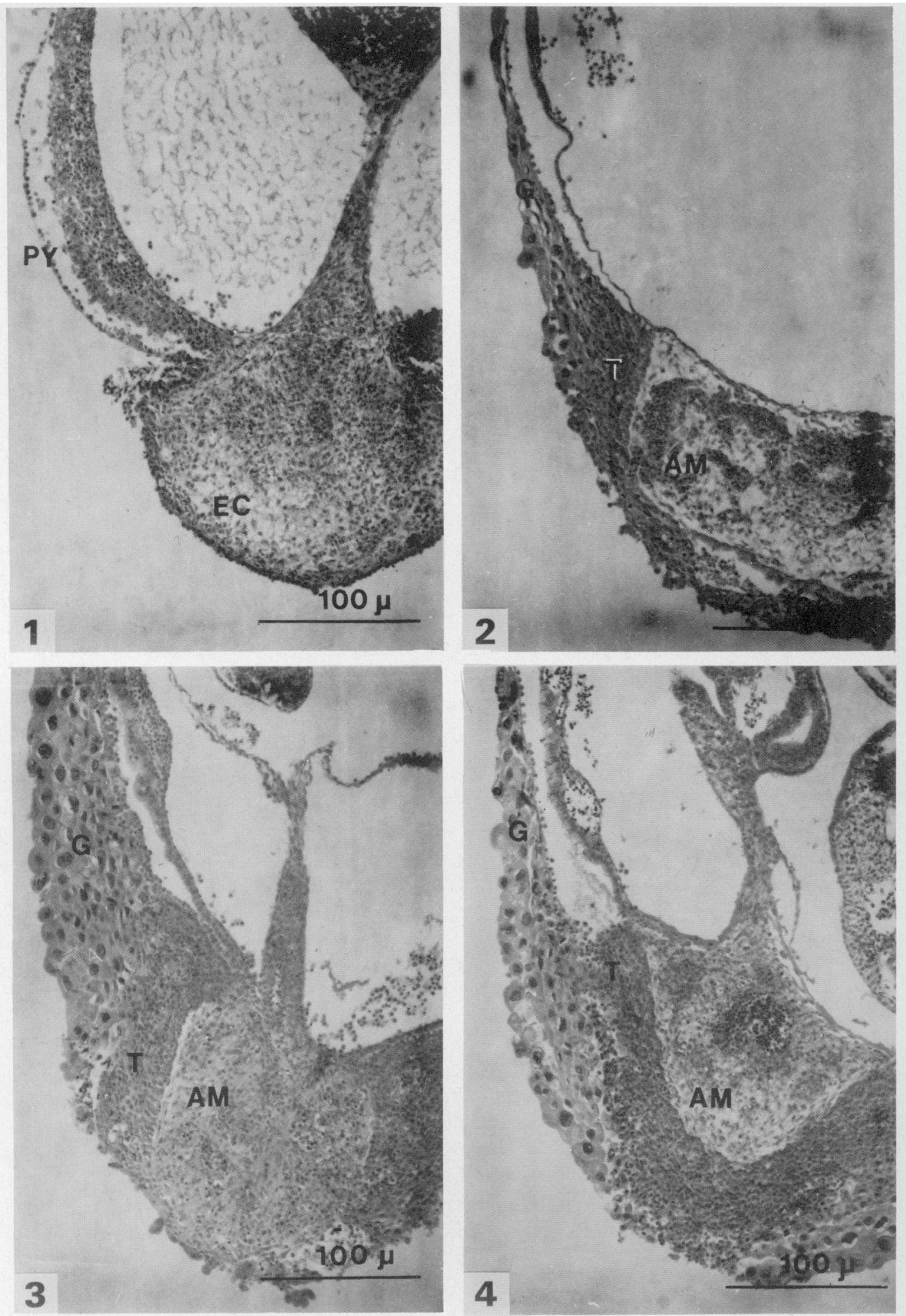

(Facing p. 300) 
PIATE:
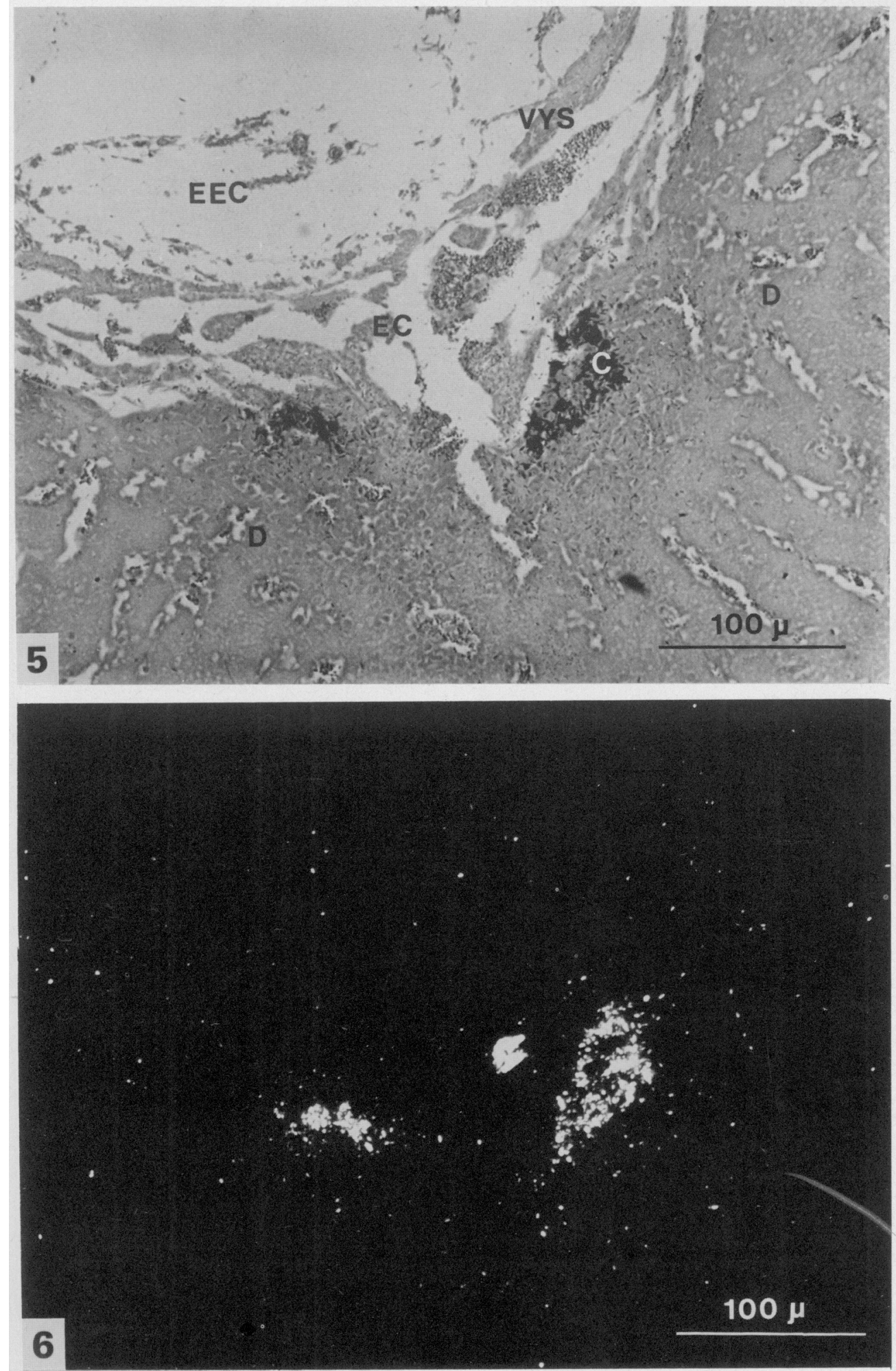
test-tubes wiped dry and the pellet extracted with detergents as described below. Preliminary experiments showed that when intact spermatozoa were treated in an identical fashion the pattern of labelled proteins obtained after separation on SDS polyacrylamide gels was identical to that found when spermatozoa were washed through sucrose.

Extraction of proteins from spermatozoa. Spermatozoa were extracted with $0 \cdot 2 \%$ sodium deoxycholate in $0.264 \mathrm{M}$-sucrose buffer $\mathrm{pH} 8.0$ at $4^{\circ} \mathrm{C}$ for $45 \mathrm{~min}$ and centrifuged at $1000 \mathrm{~g}$ for 10 $\mathrm{min}$. The supernatants were removed, re-centrifuged at $10000 \mathrm{~g}$ for $10 \mathrm{~min}$ and stored frozen at $-20^{\circ} \mathrm{C}$. The $1000 \mathrm{~g}$ sperm pellets were then re-extracted in $0.5 \mathrm{ml} 1.0 \% \mathrm{SDS}$ in sucrose buffer $\mathrm{pH}$ 7.4. Membrane pellets were solubilized directly in $2 \%$ SDS in $62.5 \mathrm{~mm}$-Tris/ $\mathrm{HCl} \mathrm{pH} 7 \cdot 4$.

Electrophoresis and detection of labelled proteins. Proteins were precipitated with 9 volumes of absolute ethanol, centrifuged at $10000 \mathrm{~g}$ for $10 \mathrm{~min}$ and the pellets solubilized by boiling for $3 \mathrm{~min}$ in $110 \mu \mathrm{l} 62.5 \mathrm{mM}$-Tris/ $\mathrm{HCl} \mathrm{pH} 7.2$ containing $1 \% \mathrm{SDS}$ and $1 \% 2$-mercaptoethanol. A portion was removed for counting or protein determination (by absorption at $280 \mathrm{~mm}$ ) and equal counts or amounts of protein were applied to each track of a $15 \%$ polyacrylamide slab gel containing $1 \%$ SDS (Jones, Brown, von Glos \& Parker, 1980). Proteins were stained with 0.05\% Coomassie Brilliant Blue or Amido Black in an aqueous solution of $40 \%$ methanol and $7 \%$ acetic acid for $60 \mathrm{~min}$ at room temperature, and destained overnight in the same solvent without dye. Relative amounts of protein were quantified by densitometry, using an integrating densitometer (Helena Laboratories) to calculate relative areas. Labelled proteins were detected by autoradiography on pre-flashed film (Kodak X-Omat $\mathrm{H}$ ) and quantified by densitometry. The results shown are representative of the data as a whole.

\section{Results}

\section{Evaluation of cellular integrity}

Initial experiments were designed to evaluate procedures which would wash all unbound extracellular secretions from spermatozoa whilst preserving the integrity of the plasma membrane. The suitability of sucrose-based diluents for preserving the viability of spermatozoa and the efficacy of a sucrose gradient for removing seminal plasma have been investigated for a number of species (Harrison, Dott \& Foster, 1978): these procedures remove approximately $99 \%$ of extracellular secretions whilst preserving the motility and fertilizing ability of spermatozoa.

To check sperm integrity, we compared the profile of proteins that became iodinated on 'intact' spermatozoa with those that became iodinated on spermatozoa that had been damaged deliberately by sonication, the rationale of this being that sonication would expose intracellular membranebound proteins, e.g. on the nucleus, acrosome and mitochondria, which would be iodinated in addition to those on the plasma membrane. These intracellular proteins could then be used as markers for assessing cellular integrity. A total of 8 proteins were labelled on intact cauda epididymal spermatozoa when detergent-extracted proteins were separated on SDS polyacrylamide gels (Text-fig. 1). However, approximately 15 proteins were labelled on damaged spermatozoa, indicating that several intracellular membrane-bound proteins had been exposed to lactoperoxidase.

\section{Comparison of total detergent-soluble proteins in testicular and cauda epididymal spermatozoa}

Preliminary experiments showed that the rate of solubilization of total protein from washed testicular and cauda epididymal spermatozoa incubated in $0.2 \%$ deoxycholate reached a plateau after incubation for $45 \mathrm{~min}$ at $4^{\circ} \mathrm{C}$. A comparison of the profile of proteins extracted with detergent from testicular and cauda epididymal spermatozoa after analysis on $15 \%$ polyacrylamide gels containing SDS is shown in Pl. 1, Fig. 1. Approximately 40 proteins, with molecular weights ranging from 12500 to 110000 , were resolved in the sperm extracts. High molecular weight 


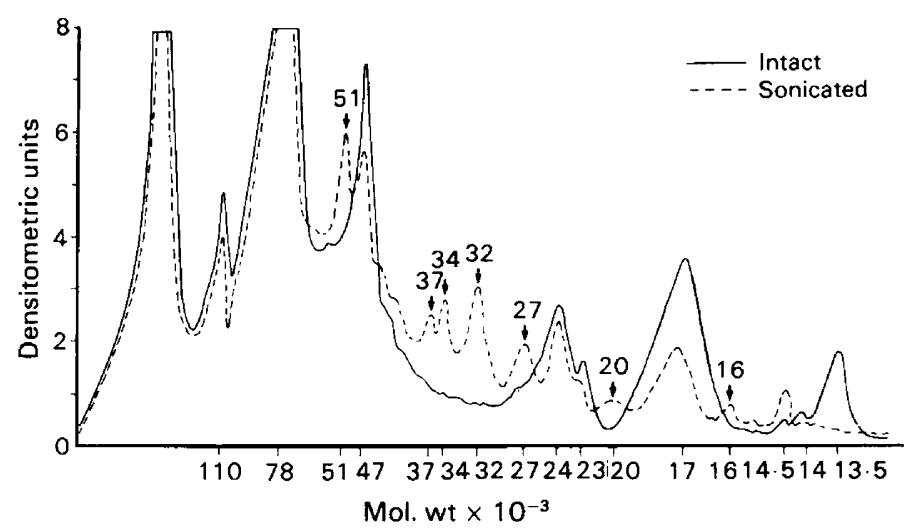

Text-fig. 1. Comparison of iodinated proteins extracted from intact and sonicated spermatozoa from the rat cauda epididymidis after separation on SDS polyacrylamide gels. Labelled proteins were detected by autoradiography and total incorporation of ${ }^{125} \mathrm{I}$ was calculated by combining densitometric scans of deoxycholate and SDS extracts.

proteins $(>120000)$ were also observed but were not investigated further. Densitometric estimations of each protein in total detergent extracts (i.e. deoxycholate + SDS), showed that the relative amounts of proteins with molecular weights of about $14000,14500,16000,21000,25500$, $27000,31000,34000,37000,64000,66000,84000$ and 94000 decreased during passage of spermatozoa from the testis to the cauda epididymidis, proteins with molecular weights of about $13000,13500,17000,18500,19000$ and 47000 increased, whilst the remainder showed little or no detectable change.

Comparison of proteins in a membrane preparation from testicular and cauda epididymal spermatozoa

Since detergent extracts of whole spermatozoa contain water-soluble proteins as well as those previously bound to membranes, the type of proteins present in a membrane preparation was investigated. A membrane preparation from testicular spermatozoa showed a different profile of proteins stainable with Coomassie Blue than did a membrane preparation from cauda epididymal spermatozoa (Pl. 2, Fig. 2). A major difference was the presence of relatively large amounts of the $M_{r} 21000$ protein in testicular sperm membranes, although such a preparation must have contained membranes from a variety of sources, e.g. acrosome, as well as the plasma membrane, since no attempt was made to purify the latter. The composition of proteins in rete testes fluid and cauda epididymal plasma are also shown for comparison (P1. 2, Fig. 2, tracks 1 \& 2).

\section{Iodination of plasma membrane proteins on testicular and cauda epididymal spermatozoa}

The rate of incorporation of ${ }^{125} \mathrm{I}$ into protein was rapid during the first $5 \mathrm{~min}$ for testicular and cauda epididymal spermatozoa (Text-fig. 2), but thereafter it declined sharply with only a $12 \%$ increase during the next $15 \mathrm{~min}$. Therefore, in all subsequent experiments iodination was terminated after reaction for $3 \mathrm{~min}$. The incorporation of ${ }^{125} \mathrm{I}$ into protein in the absence of lactoperoxidase was consistently $<2 \%$ of that in the presence of the enzyme. Delipidation of acidinsoluble material collected on filters caused a $24 \%$ and $29 \%$ decrease in radioactivity associated with testicular and cauda epididymal spermatozoa respectively, suggesting that some of the iodinated proteins are very hydrophobic or are associated with lipids.

Analysis of detergent-extracted proteins on SDS polyacrylamide gels followed by autoradiography revealed a heavily iodinated protein of $M_{r} \sim 78000$ on testicular and epididymal spermatozoa (Text-fig. 3). However, further experiments showed that this represented 
PLATE 1

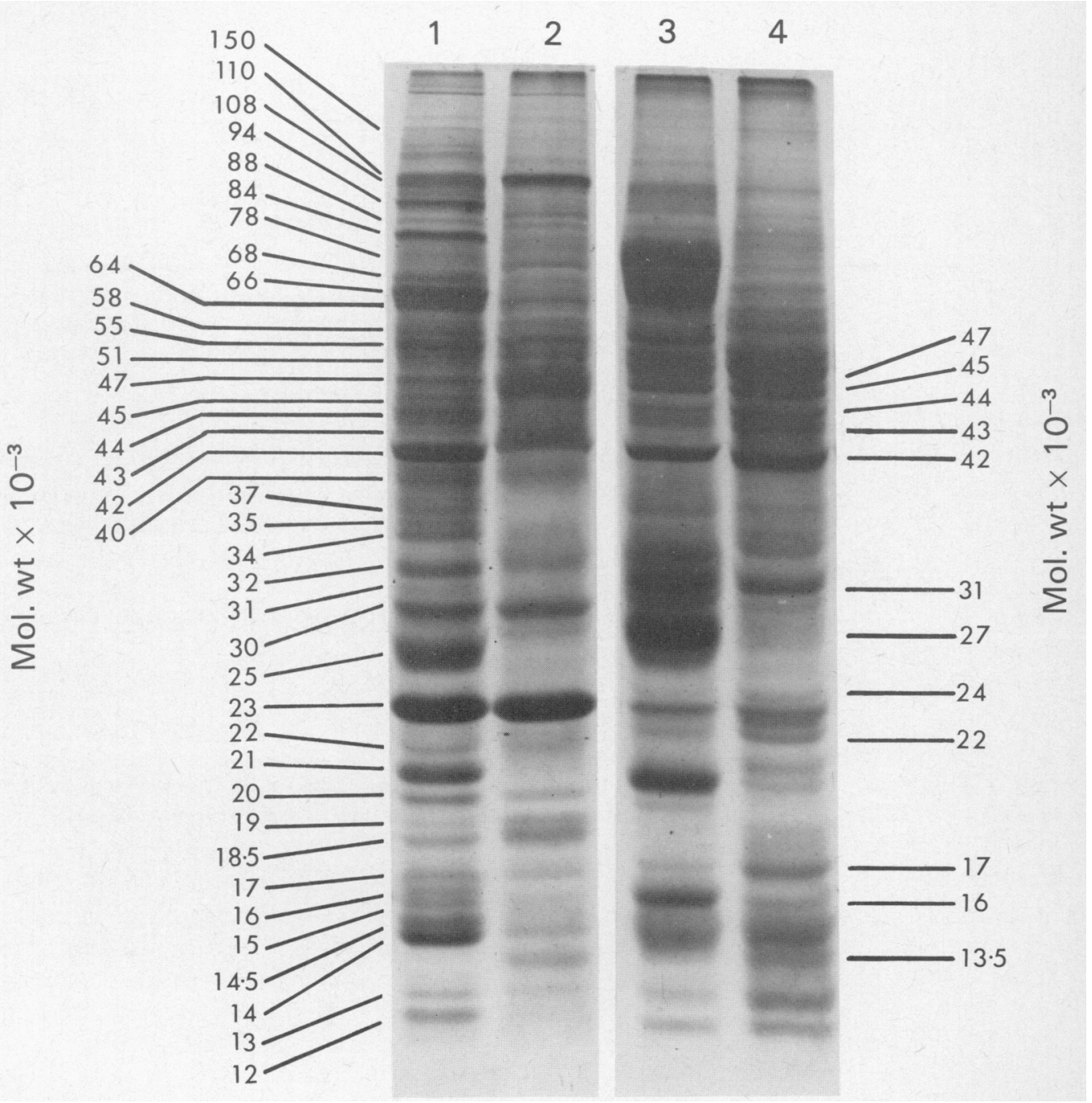

Fig. 1. SDS polyacrylamide gel electrophoresis of proteins extracted with sodium deoxycholate (tracks 1 and 2) and SDS (tracks 3 and 4) from intact spermatozoa from the testis (tracks 1 and 3 ) and cauda epididymidis (tracks 2 and 4). Proteins were stained with Coomassie Blue and values given are approximate molecular weights. Each track received $100 \mu \mathrm{g}$ protein. 
PLATE 2

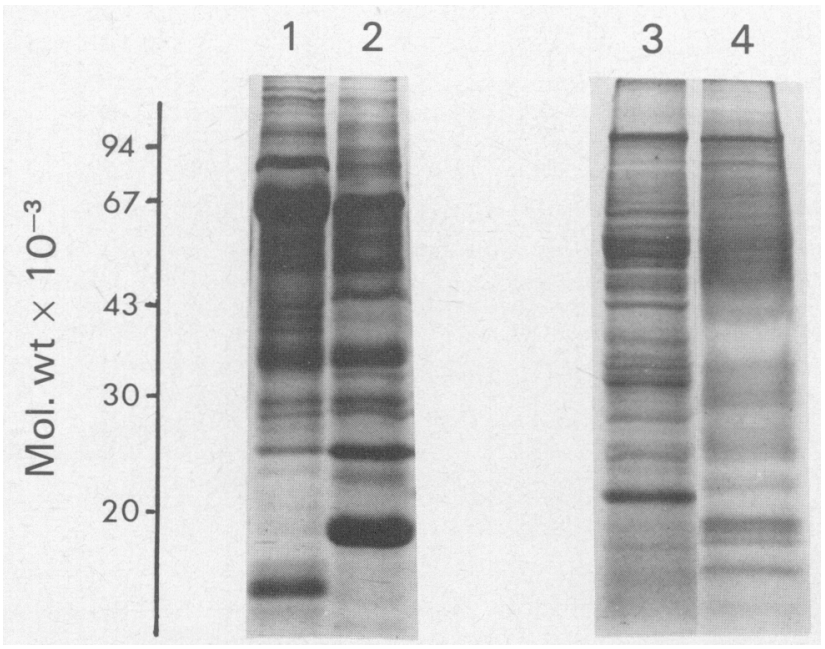

Fig. 2. SDS polyacrylamide gel electrophoresis of proteins in rete testis fluid (track 1), cauda epididymal plasma (track 2) and in a membrane preparation from testicular (track 3) and cauda epididymal spermatozoa (track 4). Proteins were stained with Coomassie Blue and values given are approximate molecular weights. Each track received $100 \mu \mathrm{g}$ protein. 


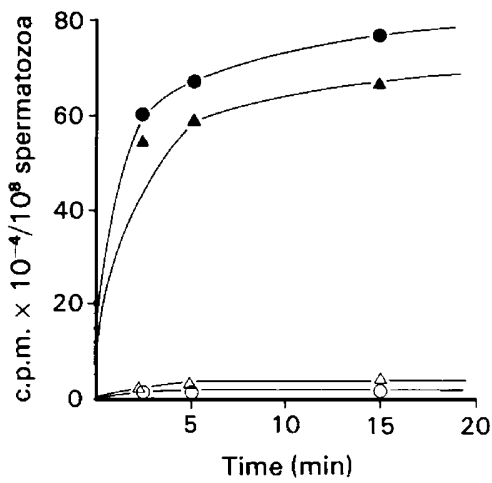

Text-fig. 2. Time-course of the incorporation of ${ }^{125} \mathrm{I}$ into total acid-insoluble protein on intact testicular $(\boldsymbol{O})$ and cauda epididymal spermatozoa $(\boldsymbol{\Lambda})$ in the presence of lactoperoxidase. $O$, $\triangle$, Incorporation in the absence of lactoperoxidase.

lactoperoxidase itself $\left(M_{r} \sim 77500\right)$ which is 'adsorbed' non-specifically onto the sperm membrane and then iodinated. This binding of lactoperoxidase to the sperm plasma membrane has not been reported previously, although in several instances when spermatozoa have been iodinated by this technique labelled proteins have been found in the region of $M_{r} 70000-80000$ (Nicolson et al., 1979; Olson \& Danzo, 1981; Wong, Tsang \& Lee, 1982). The total amount of lactoperoxidase binding to spermatozoa was in the microgram range as it could be detected with Coomassie Blue; control spermatozoa incubated without lactoperoxidase showed only a small amount of protein in the $M_{r} 78000$ region. It was noticeable that 3-4 times more enzyme bound to testicular spermatozoa than to spermatozoa from the cauda epididymidis. Nonetheless, over and above this artefact there were several important differences between the two types of spermatozoa in the nature of the proteins iodinated. Analysis of deoxycholate- and SDS-extracted proteins from testicular spermatozoa revealed 10 labelled proteins with approximate molecular weights ranging from 14000 to 150000 (Text-fig. 3). Neglecting the artefactual labelling of the lactoperoxidase, the most intensely iodinated sperm protein had an $\mathrm{M}_{\mathrm{r}}$ of $\sim 110000$ and accounted for $32 \%$ of the total label incorporated. By contrast, 8 proteins on cauda epididymal spermatozoa were iodinated (Textfig. 3), only 2 of which, $M_{r} 17000$ and 110000 , corresponded to proteins on testicular spermatozoa.

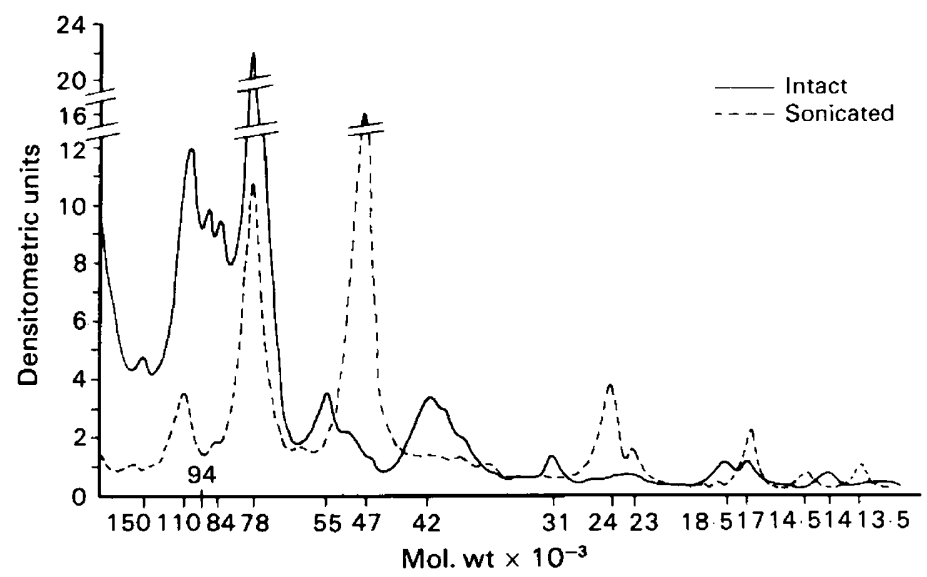

Text-fig. 3. Comparison of membrane-bound proteins which label with lactoperoxidase- ${ }^{125} I$ on intact testicular and cauda epididymal spermatozoa after separation on SDS polyacrylamide gels. Labelled proteins were detected by autoradiography and total incorporation of ${ }^{125} \mathrm{I}$ was calculated by combining densitometric scans of deoxycholate and SDS extracts. 
Instead, $60 \%$ of the ${ }^{125} \mathrm{I}$ incorporated was localized in a protein of $\mathrm{M}_{\mathrm{r}} \sim 47000$ and $12 \%$ in one of $M_{r} \sim 24000$. Other labelled proteins are shown in Text-fig. 3. More radioactivity was detected in the protein of $M_{r} 17000$ than in the corresponding protein on testicular spermatozoa whereas the converse was true for the $M_{r} 110000$ protein. For spermatozoa from both sites, a significant amount of radio-label was associated with high molecular weight proteins $(>200000)$ which did not penetrate the separating gel by more than $1 \mathrm{~mm}$. No attempt was made to identify these proteins.

\section{Discussion}

An important requirement in all whole cell labelling experiments is that the cell suspension should be homogeneous. Surprisingly, insufficient attention has been paid to this problem and previous workers have collected spermatozoa from the epididymis simply by mincing the tissue in PBS. In our experience spermatozoa obtained in this way are always contaminated with some lymphatic and epididymal epithelial cells and, unless purified further, are unsuitable for experiments of the kind described here. However, spermatozoa collected directly from the rete testis, or flushed from the cauda epididymidis, are consistently of high purity, confirming our belief that any differences we observe between the two cell suspensions reflect changes to spermatozoa alone, and not varying amounts of contaminating tissue cells.

The decrease in the total amount of protein extractable with detergents during maturation of spermatozoa in the epididymis is not a generalized effect but appears to be caused by a loss of specific proteins. The fact that the amount of certain proteins decreases substantially during maturation, e.g. the 21000 protein, whereas others do not change, e.g. the $M_{r} 23000$ protein, suggests that they leak out of spermatozoa during passage through the epididymis, or that they are preferentially removed from membranes, or both. The presence of a protein of $M_{r} 21000$ in a membrane preparation from testicular spermatozoa but its absence from epididymal spermatozoa and secretions argues against its direct removal and accumulation in the luminal fluid during passage of spermatozoa through the epididymis. Lavon et al. (1971) speculated that these changes may be due to proteolytic degradation of membrane proteins, brought about by hydrolytic enzymes in epididymal secretions. If so, then it is highly selective and efficient because none of the proteins removed from testicular spermatozoa are present in cauda epididymal plasma. The epididymis synthesizes a variety of hydrolytic enzymes (Jones, 1978) and it may be that they are secreted in a zymogen form, to be activated later by more favourable conditions of $\mathrm{pH}$ or calcium ion concentration, for example.

Significant differences between testicular and cauda epididymal spermatozoa were also apparent in the profile of proteins in a membrane preparation (P1. 2, Fig. 2). The overall impression was again one of a loss of proteins from membranes during epididymal maturation. The $\mathbf{M}_{\mathrm{r}} 23000$ protein, which was a major component in detergent extracts of both types of spermatozoa, was present in relatively small amounts in membrane preparations, suggesting that it is not an integral membrane protein but is easily detached from the cell surface. The $M_{r} 23000$ protein is a major epididymal secretory protein although it is also present in rete testis fluid (Pl. 2, Fig. 2). We have shown that this protein possesses significant $\alpha$-lactalbumin-like activity (Jones \& Brown, 1982). Its position on the cell surface suggests that it may be involved in regulating glycosylation of existing membrane proteins (Hamilton, 1981; Jones \& Brown, 1982). By contrast, there was no significant diminution in the relative amounts of the proteins of $M_{r} 18500$ and 19000 in membrane preparations from cauda epididymal spermatozoa (compare track 2, Pl. 1, Fig. 1 with track 8, Pl. 2, Fig. 2), suggesting they are firmly bound to the plasma membrane. We have shown these proteins are homologous with the 2 androgen-dependent proteins synthesized and secreted in the caput epididymidis (Jones et al., 1980; Jones \& Brown, 1982). It may be, therefore, that some epididymal secretory proteins are fully integrated into the plasma membrane during maturation whereas others are only loosely attached. 
Although several workers have used lactoperoxidase-catalysed iodination techniques to label membrane proteins on spermatozoa, there have been few attempts to ascertain if the enzymic labelling was confined solely to the cell surface or to optimize the reaction conditions without affecting cell viability. If the plasma membrane of a small proportion $(\sim 5 \%)$ of cells is permeable and lactoperoxidase has access to intracellular proteins then spurious results can be obtained (Juliano \& Behar-Bannelier, 1975), especially if the intracellular proteins label with higher specific activity than the plasma membrane proteins. This emphasizes the need to include controls consisting of cells that have been damaged deliberately to help identify those intracellular proteins that are susceptible to iodination, and then to use these proteins as markers for assessing membrane permeability. Furthermore, the deleterious effects of $\mathrm{H}_{2} \mathrm{O}_{2}$ and iodination on membrane proteins and lipids should be seriously considered in view of reports of lipid peroxidation (Welton \& Aust, 1972), cell cytotoxicity (Edelson \& Cohn, 1973) and loss of viral infectivity (Brewer \& Singer, 1974) after iodination. As little as $5 \mu \mathrm{M}-\mathrm{H}_{2} \mathrm{O}_{2}$ added to liver microsomes caused significant lipid peroxidation and inhibition of cytochrome P450 (Welton \& Aust, 1972). In view of the toxicity of $\mathrm{H}_{2} \mathrm{O}_{2}$ to spermatozoa (VanDemark, Salisbury \& Bratton, 1949; Wales, White \& Lamond, 1958) and the unusual lability of their lipids to peroxidation (Jones \& Mann, 1976) it was important to investigate conditions which would avoid membrane perturbation and the possibility of labelling intracellular membrane proteins, whilst ensuring adequate incorporation of ${ }^{125} \mathrm{I}$. Our results show that, when the glucose-glucose oxidase system is used to generate a continuous micromolar supply of $\mathrm{H}_{2} \mathrm{O}_{2}$ close to its rate of consumption, nearly maximum incorporation of ${ }^{125} \mathrm{I}$ into protein is obtained within $3 \mathrm{~min}$. The enzymic system also eliminates the periodic addition of small quantities of concentrated $\mathrm{H}_{2} \mathrm{O}_{2}$ which might cause transient gradients of harmful amounts of peroxide.

More proteins were iodinated on spermatozoa damaged by sonication than on spermatozoa whose integrity had been preserved. This suggests that these additional proteins are located on intracellular membranes or that sonication 'exposes' in some way proteins on the plasma membrane not normally available to lactoperoxidase. In view of the presence of significant amounts of intracellular membranes, e.g. acrosomal membranes, it is likely that many of these additional labelled proteins are internal to the plasma membrane. In none of our experiments with intact spermatozoa did we observe iodination of the 7 additional proteins found after sonication.

The significant differences between testicular and cauda epididymal spermatozoa in the nature of the proteins iodinated suggest a substantial re-organization of the plasma membrane during maturation. Many plasma membrane proteins may not label because of the lack of exposed tyrosine or histidine residues or other problems associated with this technique (Hubbard \& Cohn, 1976). Nonetheless, the fact that on testicular spermatozoa the most heavily labelled proteins have molecular weights of approximately $110000,94000,84000$ and 55000 whereas on cauda epididymal spermatozoa only proteins with molecular weights of approximately 47000,24000 , $23000,17000,14500$ and 13500 incorporate ${ }^{125} \mathrm{I}$ is indicative of real organizational changes. Many of the proteins that became strongly iodinated were relatively minor components of the total detergent-extractable protein as judged by their ability to bind Coomassie Blue. Identification of the $M_{r} 47000$ protein as the androgen-dependent protein synthesized specifically in the cauda epididymidis (Jones et al., 1980) is tentative and must await immunological verification. It will be important in future work to determine the orientation of proteins in the plasma membrane, the sequence and precise region of the epididymis where the organizational changes are effected, and ultimately their relationship to the acquisition of motility and fertilizing ability by spermatozoa.

We thank Mrs M. Mansfield and Mrs J. Constable for typing the manuscript.

\section{References}

Barker, L.D.S. \& Amann, R.P. (1971) Epididymal physiology. II. Immunofluorescent analyses of epithelial secretion and absorption, and of bovine sperm maturation. J. Reprod. Fert. 26, 319-332.
Bedford, J.M. (1975) Maturation, transport and fate of spermatozoa in the epididymis. In Handbook of Physiology, vol. 5, pp. 303-317. Williams \& Wilkins Co., Baltimore. 
Brewer, G. J. \& Singer, S.J. (1974) On the disposition of the proteins of the membrane-containing bacteriophage PM2. Biochemistry, N.Y. 13, 3580-3588.

Brooks, D.E. \& Higgins, S.J. (1980) Characterization and androgen-dependence of proteins associated with luminal fluid and spermatozoa in the rat epididymis. J. Reprod. Fert. 59, 363-375.

Edelson, P.J. \& Cohn, Z.A. (1973) Peroxidase-mediated mammalian cell cytotoxicity. J. exp. Med. 138, 318323.

Flechon, J.-E. (1974) Freeze-fracturing of rabbit spermatozoa. J. Microscopie 19, 59-64.

Hamilton, D.W. (1981) Evidence for $\alpha$-lactalbumin-like activity in reproductive tract fluids of the male rat. Biol. Reprod. 25, 385-392.

Harrison, R.A.P., Dott, H.M. \& Foster, G.C. (1978) Effect of ionic strength, serum albumin and other macromolecules on the maintenance of motility and the surface of mammalian spermatozoa in a simple medium. J. Reprod. Fert. 52, 65-73.

Hubbard, A.L. \& Cohn, Z.A. (1976) Specific labels for cell surfaces. In Biochemical Analysis of Membrane, pp. 427-501. Ed. A. H. Maddy. Chapman \& Hall Ltd, London.

Jones, R. (1978) Comparative biochemistry of mammalian epididymal plasma. Comp. Biochem. Physiol. 61B, 365-370.

Jones, R. \& Brown, C.R. (1982) Association of epididymal secretory proteins showing $\alpha$-lactalbumin-like activity with the plasma membrane of rat spermatozoa. Biochem. J. 206, 161-164.

Jones, R. \& Mann, T. (1976) Lipid peroxidation in spermatozoa; formation, role of plasmalogen and physiological significance. Proc. R. Soc. B 193, 317333.

Jones, R., Brown, C.R., von Glos, K.I. \& Parker, M.G. (1980) Hormonal regulation of protein synthesis in the rat epididymis. Characterization of androgendependent and testicular fluid-dependent proteins. Biochem. J. 188, 667-676.

Jones, R., Pholpramool, C., Setchell, B.P. \& Brown, C.R. (1981) Labelling of membrane glycoproteins on rat spermatozoa collected from different regions of the epididymis. Biochem. J. 200, 457-460.

Juliano, R.L. \& Behar-Bannelier, M. (1975) An evaluation of techniques for labelling the surface proteins of cultured mammalian cells. Biochim. Biophys. Acta 375, 249-267.

Koehler, J.K. (1970) A freeze-etching study of rabbit spermatozoa with particular reference to head structures. J. Ultrastruct. Res. 33, 598-615.

Koehler, J.K. (1981) Lectins as probes of the spermatozoon surface. Arch. Androl. 6, 197-217.
Lavon, U., Volcani, R. \& Danon, D. (1971) The proteins of bovine spermatozoa from the caput and cauda epididymidis. J. Reprod. Fert. 24, 219-232.

Lea, O.A., Petrusz, P. \& French, F.S. (1978) Purification and localization of acidic epididymal glycoprotein (AEG): a sperm coating protein secreted by the rat epididymis. Int. J. Androl., Suppl. 2, 592-607.

Moore, H.D.M. (1980) Localization of specific glycoproteins secreted by the rabbit and hamster epididymis. Biol. Reprod. 22, 705-718.

Nicolson, G.L., Brodginski, A.B., Beattie, G. \& Yanagimachi, R. (1979) Cell surface changes in the proteins of rabbit spermatozoa during epididymal passage. Gamete Res. 2, 153-162.

Oliphant, G. \& Singhas, C.A. (1979) Iodination of rabbit sperm plasma membrane: relationship of specific surface proteins to epididymal function and sperm capacitation. Biol. Reprod. 21, 937-944.

Olson, G.E. \& Danzo, B.J. (1981) Surface changes in rat spermatozoa during epididymal transit. Biol. Reprod. 24, 431-443.

Olson, G.E. \& Hamilton, D.W. (1978) Characterization of the surface glycoproteins of rat spermatozoa. Biol. Reprod. 19, 26-35.

Suzuki, F. \& Nagano, T. (1980) Epididymal maturation of rat spermatozoa studied by thin sectioning and freeze-fracture. Biol. Reprod. 22, 1219-1231.

VanDemark, N.L., Salisbury, G.W. \& Bratton, R.W. (1949) Oxygen damage to bull spermatozoa and its prevention by catalase. J. Dairy Sci. 32, 353-360.

Vierula, M. \& Rajaniemi, H. (1980) Radioiodination of surface proteins of bull spermatozoa and their characterization by sodium dodecyl sulphate-polyacrylamide gel electrophoresis. J. Reprod. Fert. 58, 483-489.

Voglmayr, J.K., Fairbanks, G., Jackowitz, M.A. \& Colella, J. (1980) Post-testicular developmental changes in the ram sperm cell surface and their relationship to luminal fluid proteins of the reproductive tract. Biol. Reprod. 22, 655-667.

Wales, R.G., White, I.G. \& Lamond, D.R. (1958) The spermicidal activity of hydrogen peroxide in vitro and in vivo. $J$. Endocr. 18, 236-244.

Welton, A.F. \& Aust, S.D. (1972) Lipid peroxidation during enzymatic iodination of rat liver reticulum. Biochim. Biophys. Res. Commun. 49, 661-666.

Wong, P.Y.D., Tsang, A.Y.F. \& Lee, W.M. (1982) Secretion of macromolecules by the rat epididymis. Int. J. Androl., Suppl. 5, 34-47.

Young, L.G. \& Goodman, S.A. (1980) Characterization of human sperm cell surface components. Biol. Reprod. 23, 826-835. 